\title{
The Effect of Audit Results and Financial Performance on Corruption Level Moderated by Government Size
}

\author{
Submitted 23/03/19, 1st revision 14/04/19, 2nd revision 23/05/19, accepted 30/07/19
}

\author{
Kiswanto $^{1}$, Ain Hajawiyah ${ }^{2}$, Nani Fitriani ${ }^{3}$
}

\begin{abstract}
:
Purpose: This paper aims to examine the effect of audit results and financial performance on corruption level taking into consideration the effect of government size as a moderating variable.

Design/Methodology/Approach: The population of the study is the Indonesian provincial government for the period 2012-2015. The sampling technique used is purposive sampling with 123 unit analysis. The data analysis technique used is the absolute difference method test, F test, and coefficient determination (R2) test.

Findings: The study shows that audit results that are consistent with audit findings, postaudit follow up actions, and independence ratio have a positive effect on corruption level. Meanwhile, financial performance doesn't have a significant effect on corruption level.

Practical Implications: This study has practical implications on factors affecting corruption level. The provincial government should strengthen its supervision and improve its internal control effectiveness to reduce corruption.

Originality/Value: This paper was original in terms of government size as the moderating variable in the proposed model.
\end{abstract}

Keywords: Audit results, financial performance, government size, corruption.

JEL codes: G30, G32.

Paper type: Research article.

\footnotetext{
${ }^{1}$ Universitas Negeri Semarang - Department of Accounting, kiswanto@mail.unnes.ac.id

${ }^{2}$ Corresponding author, Universtas Negeri Semarang, Department of Accounting, ainhajawiyah@mail.unnes.ac.id

${ }^{3}$ Universitas Negeri Semarang - Department of Accounting
} 


\section{Introduction}

Any government should manage the natural resources over all regions. It is supported by the theory of autonomous regions. The aim of autonomous regions is to efficiently and effectively manage the utilization of resources in each region independently (De Asis, 2006). On the other hand, the existence of regional autonomy has problems related to the implementation of regional finance which is prone to be corrupted. According to Liu \& Lin (2012), among other sectors, the public financial sector is very precarious to be corrupted.

Corruption is a problem which all governments, at any level, have to deal with (Balboa \& Medalla, 2006). Private sector corruption would seem more prevalent in developed economies, while public sector corruption is common in developing economies (Mugarura, 2016). International Transparency found that developing countries such as Haiti, Bangladesh, Nigeria, Myanmar, Chad, and Paraguay have Corruption Perceptions Index (CPI) less than 5 in 2004 (score 10 shows clean government). While rich countries such as Finland, Denmark, New Zealand, Iceland, Singapore, and Sweden have 9 CPI scores (Cavill \& Sohail, 2007).

Indonesia Corruption Watch (ICW) data in the first semester of 2016 showed that the detriment from corruption in Indonesia reached Rp. 890.5 billion (Wijaya, 2018). The regulation made by the government should be able to reduce the size of corruption in Indonesia, especially in terms of licensing simplification. Transparency by the government also supports the prevention and reduction of corruption, but the level of corruption of the government, especially the regional government, is still very high.

Many studies claimed the causes of corruption includes macro, law, accounting and auditing aspects. According to Balboa \& Medalla (2006), anti-corruption strategies reduced corruption opportunities by policy reformation and deregulation also increasing public awareness in Philiphines. According to Shabbir \& Anwar (2007), economic determinants of corruption are economic freedom, globalization, education level, economic development and income distribution. Researches on corruption that uses audit and accounting determinants examine variables such as the result of audit board reports, financial performance variables and government size.

This study examines the effect of the Audit Board of Indonesia audit results and financial performance on corruption. The Audit Board of Indonesia audit results consist of audit findings and follow up by audit recommendations. The financial performance in this study is the independence ratio and activity ratio. Liu and Lin (2012) found that the government audits and follow-up on audit recommendations have positive and negative effects on corruption. Rini and Damiati (2017) shows that the results of the audit findings did not affect corruption while according to Barwi and Solikhah (2018) both audit findings and follow-up recommendations do not affect corruption. 
Financial performance variables are rarely investigated as corruption causes. The previous study related to financial performance is the research of Heriningsih and Marita (2013) showing that financial performance had no effect on corruption. Anthos (2018) stated that regional financial independence ratios have a significant effect on corruption and the activity ratio has no effect on corruption. Nugroho (2016) shows that the activity ratio affects corruption while the independence ratio does not affect corruption. Thus, the researcher added the size of the government as a moderating variable in financial performance against corruption.

The study focused on the level of provincial government corruption cases. This study aims to find empirical evidence of the effect of Audit Board of Indonesia audit result and the government's financial performance on the level of corruption with government size as moderating variable which is the originality of this study. This research is expected to provide a contribution in the literature by expanding the study of corruption with a focus in accounting aspects.

\section{Research Hypotheses}

The study used two theories, agency and signaling theory. Agency theory assumes that once principals delegate authority to agents, they often have problems in controlling them. Agents' goals differ from principal's goals while agents have better information about their capacity than principals (Kivistö, 2007). The different goals between principals and agents cause agency problems (Jensen \& Meckling, 1976).

Signaling theory provides a framework for interpreting information transmitted at an initial encounter (Dunham \& Cronk, 2010). Because some information is private, asymmetries arise between those who hold the information and those who could potentially make better decisions if they had access on it (Connelly, 2011). Evans \& Patton (1987) stated that government as the party given the mandate from the people wants to show signal to the public. Independent audit is one of the way to increase the reliability of information disclosed by the government to the public.

The Audit Board of Indonesia's findings are measured by the findings of noncompliance with laws and regulations. Audit Board of Indonesia's findings indicate the level of accountability of the financial statements of a local government (Lukfiarini, 2018). Compliance with laws and regulations reflect the performance of agencies that are adjusted to the standards set by the statutory regulations. Liu \& Lin (2012) stated that strict regulations, especially forms of punishment, can reduce the level of corruption.

Agency theory states that government and society relations create conflict of interest. Conflict of interest creates opportunistic action, humans will prioritize personal interests than the organization (Jensen \& Meckling, 1976). Compliance to the laws and regulations reflects the performance of agencies that are adjusted to the 
standards set by the statutory regulations. Liu \& Lin (2012) states that the higher the findings of the audit, the higher the possibility of corruption. It is assumed that the higher level of compliance with laws and regulations, the level of potential corruption will decrease. Therefore the research hypothesis is:

H1: Audit Board of Indonesia findings have a positive effect on the level of corruption.

Audit findings follow-up actions is more important than the audit result itself because it will increase audit effectivity (Liu \& Lin, 2012). Based on agency theory, humans will be opportunistic which means that humans will prioritize personal interests than organization interests. Higher follow-up action of audit result will reduce principals' opportunistic actions. Liu \& Lin (2012) stated that corruption level decrease by the growing of follow-up action of audit result. Therefore, it is hypothesized that the higher the follow-up recommendations on Audit Board of Indonesia's audit result will reduce the level of corruption. Rini \& Damiati (2017) found that the follow-up variable of audit results had an effect in reducing the number of corruption cases that existed in the provincial government in Indonesia. The same result was found by Liu \& Lin (2012), Masyitoh et al. (2015) and Lukfiarini (2018). The new hypothesis is:

\section{H2: Audit findings follow-up action have negative effects on corruption levels.}

The regional financial independence ratio shows the ability of a region in selffinancing the government activities, development, and services to the society (Adhiantoko, 2013). Through the submission of the regional government's financial statement, the financial performance of the local government can be known by the society as a principal, so they can participate in monitoring the government. Regional government's financial statement is published in order to minimize information asymmetry as explained in signaling theory. Spence (2002) stated that signaling theory focuses on minimizing the information asymmetry. Heriningsih \& Marita (2013) stated that the higher the independence ratio, the higher social participation in paying regional taxes and retributions. This will reflect high level of social welfare and could reduce the level of corruption. According to Anthos (2018), the independence ratio has a negative effect on corruption. Therefore a new research hypothesis can be stated as:

\section{H3: Independence ratio has a negative effect on the corruption level.}

Activity ratio indicates that local governments prioritize their fund's allocation in operating expenditure optimally (Zuhri \& Soleh, 2014). The higher the activity ratio, the better the financial performance of the government. The signaling theory states that agents will provide signals regarding the performance of agents for principals. The signal given by the regional government is in the form of Local Government Financial Reports. The audited Local Government Financial Reports shows the 
quality of government financial performance. The better the activity ratio of the government, the lower the corruption level in the government. Heriningsih \& Marita (2013) and Anthos (2018) suggested that there is no significant influence between the activity ratio to corruption cases in local governments in Indonesia. Whereas Nugroho (2016) states that the activity ratio has a negative effect on the level of corruption of the provincial government in Indonesia. The related research hypothesis is:

\section{H4: Activity ratio has a negative effect on the level of corruption.}

The more complex an organization is, the higher the conflict of interest in the organization. Nurhasanah (2016) states that the bigger size of the agency, the higher the tendency of corruption. This in line with the research by Liu and Lin (2012), Ali and Isse (2003), Lambsdorff (2006) and Barwi \& Solikhah (2018) swing that the size of the government has a positive effect on the level of corruption. There are different results of previous studies regarding the effect of independence ratio on corruption level. This research used government size as moderating variable on the effect of financial performance on corruption level. There is no previous research that analyzes government size as a moderating variable. The research hupothesis is:

\section{H5: Government size moderating the effect of the independence ratio on corruption} levels.

Nurhasanah (2016), Hartanto \& Prabohudono (2013) and Barwi \& Solikhah (2018) stated that the government size increase corruption levels. Heriningsih \& Marita (2013) stated that the higher government capital expenditure to total expenditure, the better financial performance of the government. This will reduce the corruption level. The previous researches related to activity ratios and corruption level show different results. This study uses local government size to moderate the relationship between activity variables to the level of corruption levels testing the hypothesis as:

H6: Government size moderate the effect of activity ratios on corruption levels.

\section{Methodology}

This research uses quantitative data in examining the hypothesis. The population consist of all (34) provincial governments in Indonesia. The period coverage in this study is the period of 2012-2015. Samples are chosen using purposive sampling technique with some criterias showed in Table 1.

The dependent variable in this study is the corruption level. The independent variables consist of Audit Board of Indonesia audit findings, post audit follow up actions, independence ratio, and activity ratio while the moderating variable is government size. The descriptions regarding each variable are listed in Table 2. 
Table 1. Sample Selection Criteria

\begin{tabular}{lll}
\hline No & Criteria & Amount \\
\hline $\mathbf{1}$ & Number of provincial governments in Indonesia & 34 \\
$\mathbf{2}$ & Multiplication: number of years & 4 \\
$\mathbf{3}$ & Initial sample size & 136 \\
$\mathbf{4}$ & Exclusions: & \\
& $-\quad$ Provinces without prosecutor's office & $(12)$ \\
& $-\quad$ Incomplete data & $(3)$ \\
\hline $\mathbf{5}$ & Final sample size & 123 \\
\hline
\end{tabular}

Table 2. Variables Definition and Operationalization

\begin{tabular}{|c|c|c|c|}
\hline $\begin{array}{l}\mathbf{N} \\
\mathbf{0}\end{array}$ & Variable & Indicators & Data sources \\
\hline 1 & $\begin{array}{l}\text { Corruption (Y) (Liu } \\
\text { and Lin, 2012) }\end{array}$ & $\begin{array}{l}\text { Cases of corruption per } 10,000 \\
\text { residents. }\end{array}$ & $\begin{array}{l}\text { Indonesian Prosecutor's } \\
\text { Office Report 2012- } \\
2015 .\end{array}$ \\
\hline 2 & $\begin{array}{l}\text { Findings of Audit } \\
\text { Board of Indonesia } \\
\text { Examination (X1) } \\
\text { (Abror and } \\
\text { Haryanto, 2014) }\end{array}$ & $\begin{array}{l}\text { Findings of non-compliance } \\
\text { with laws and regulation- } \\
\text { adjusted for population (per } \\
\text { capita rupiah) }\end{array}$ & $\begin{array}{l}\text { Audit Board of Indonesia } \\
\text { 2012-2015 Audit } \\
\text { Results. }\end{array}$ \\
\hline 3 & $\begin{array}{l}\text { Post-Audit Follow } \\
\text { Up Action (X2) }\end{array}$ & $\begin{array}{l}\text { The total rupiahs submitted to } \\
\text { the State or regional treasury } \\
\text { adjusted to the number of } \\
\text { findings (percentage of follow- } \\
\text { up) }\end{array}$ & $\begin{array}{l}\text { Audit Board of Indonesia } \\
\text { 2012-2015 Audit } \\
\text { Results. }\end{array}$ \\
\hline 4 & $\begin{array}{l}\text { Regional Financial } \\
\text { Independence Ratio } \\
\text { (X3) } \\
\text { (Heriningsih and } \\
\text { Marita, 2013) }\end{array}$ & $\begin{array}{l}\frac{\text { (Regional Original Incomen }}{\text { (Transfer Income) }} \\
x 100 \%\end{array}$ & $\begin{array}{l}\text { Central Statistics Agency } \\
\text { 2012-2015. }\end{array}$ \\
\hline 5 & $\begin{array}{l}\text { Ratio of Regional } \\
\text { Financial Activities } \\
\text { (X4) (Heriningsih } \\
\text { and Marita, 2013) }\end{array}$ & Copital expenditure ratio $=\frac{\text { Total copital expenditure }}{\text { Total regional expenditure }}$ & $\begin{array}{l}\text { Central Statistics Agency } \\
\text { 2012-2015. }\end{array}$ \\
\hline 6 & $\begin{array}{l}\text { Local Government } \\
\text { Size (Z) (Masyitoh et } \\
\text { al., 2015) }\end{array}$ & $\begin{array}{l}\text { (Realization of } \\
\text { provincial government spending } \\
\text { / (Regional Gross Domestic } \\
\text { Products) x } 100 \%\end{array}$ & $\begin{array}{l}\text { Central Statistics Agency } \\
\text { (BPS) 2012-2015. }\end{array}$ \\
\hline
\end{tabular}

Source: Data processed, 2019.

Data are collected using documentation technique and analyzed using multiple linear regression with SPSS Statistics version 21 software. Hypotheses are tested by using absolute difference test. The regression model is as follows:

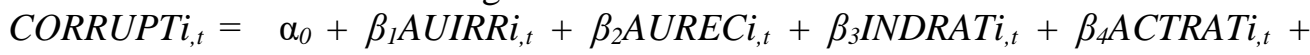
$B_{5}\left|\operatorname{INDRAT}_{i, t}-\operatorname{GOVSIZE}_{i, t}\right|+\beta_{6} \mid$ ACTRAT $_{i, t}-\operatorname{GOVSIZE}_{i, t} \mid+\varepsilon$ 
where:

CORRUPT $_{i, t} \quad$ : Corruption level;

AUIRR $_{i, t} \quad$ : Findings of Audit Board of Indonesia Examination;

$A U R E C_{i, t} \quad$ : Post-Audit Follow up Actions;

$I_{N D R A} T_{i, t} \quad:$ Regional Financial Independence ratio;

$\operatorname{ACTRAT}_{i, t} \quad$ : Ratio of Regional Financial Activities;

GOVSIZE $_{i, t} \quad$ : Local Government size.

\section{Results}

Table 3 shows descriptive statistics for all the variables used in this study. The level of corruption in the provincial government has a range from 0.0029 to 0.4420 . The lowest corruption rate occurred in Riau Islands in 2012 with 29 cases, while the highest level of corruption occurred in Central Java in 2015 with 442 cases. The data in this study passed all classic assumption tests.

Table 3. Descriptive statistics

Descriptive Statistics

\begin{tabular}{lllll}
\hline & Minimum & Maximum & Mean & Std. Deviation \\
\hline CORRUPT & 0.0029 & 0.0442 & 0.0158 & 0.0102 \\
AUIRR & 38 & 513078 & 40121 & 77039 \\
AUREC & 0.0004 & 0.7743 & 0.1404 & 0.1589 \\
INDRAT & 0.1350 & 6.3955 & 1.4553 & 1.3430 \\
ACTRAT & 0.0493 & 0.2998 & 0.1591 & 0.0600 \\
GOVSIZE & 0.0082 & 0.0942 & 0.0316 & 0.0187 \\
\hline
\end{tabular}

Based on hypothesis testing, the regression equation can be written as follows:

CORRUPT $=-4,435+0,189$ Zscore ORIRR + 0,138 ZscoreAUREC + 0,340 ZscoreINDRAT - 0,051 Zscore ACTRAT + 0,106|ZscoreINDRAT-ZscoreGOVSIZE | - 0.037|ZscoreACTRAT-ZscoreGOVSIZE | +e

Adjusted $R^{2}$ has a value of $38 \%$. The $\mathrm{F}$ test result shows significant result which means that the variations of independent variables could explain the variations of the dependent variable.

Table 4. Summary of Hypothesis Test Results

\begin{tabular}{llll}
\hline No Hypothesis & $\begin{array}{l}\text { Regression } \\
\text { Coefficient }\end{array}$ & Sig. & Results
\end{tabular}

1 The findings of the Audit Board of Indonesia $0,189 \quad 0,005$ Accepted examination have a positive effect on the level of corruption 


$\begin{array}{lllll}\mathbf{2} & \begin{array}{l}\text { Post-audit follow up action has a negative } \\ \text { effect on the level of corruption }\end{array} & 0,138 & \text { Rejected } \\ \mathbf{3} & \begin{array}{l}\text { Independence Ratio negatively affects the } 0,340 \\ \text { level of corruption } \\ \mathbf{4}\end{array} & 0,000 & \text { Rejected } \\ \mathbf{5} \quad \begin{array}{l}\text { corruption } \\ \text { Government measures moderate the effect of } \\ \text { the independence ratio on the level of } \\ \text { corruption } \\ \text { Government measures moderate the effect of - }-0,037\end{array} & 0,106 & 0,012 & \text { Accepted } \\ \text { activity ratios on corruption levels } & \text { Rejected }\end{array}$

Source: Data processed, 2019.

The Effect of Audit Board of Indonesia Audit Findings on Corruption Levels:

There is a positive effect of Audit Board of Indonesia Audit Findings on the level of corruption. This is in accordance with agency theory. The discovery of various violations by Audit Board of Indonesia indicates the existence of deviant behavior by the agent. The results of the study show that audit finding is one factor in the occurrence of corruption. Losses and potential losses from this findings must be returned to the state / regional treasury. The higher the findings of the Audit Board of Indonesia, the higher the level of corruption. This research confirms the researchers of Liu \& Lin (2012) and Masyitoh et al. (2015).

The Effect of Audit Rectifications on Corruption Level:

Follow-up of the audit results have significant positive effect on the level of corruption. This is not in accordance with agency theory. It may be happen due to lack of supervision from society. This also happens due to unsufficient fund returned as per Audit Board of Indonesia's recommendation. This research confirms Abror \& Haryanto (2014).

The Effect of Independence Ratio on Corruption Level:

Independence ratio has positive effect on the level of corruption. Eventhough the independence ratio shows good financial performance of local governments, the level of corruption is increasing. This is not in accordance with agency theory. Anthos (2018) found that the independence ratio has a significant effect on the level of corruption. Independence ratio shows the ratio of Local Revenue (PAD) to Transfer Income. The higher the income, the more complex the financial policy. Higher income provinces have a more complicated budget allocation system.

\section{The Effect of Activity Ratio on Corruption Level:}

The research proves that the activity ratio does not affect the level of corruption. This result do not support signaling theory. Government with better financial performance should have lower level of corruption. The higher activity ratio, the more effective usage of the budget. The more effective usage of the budget, the fewer opportunities to take personal benefit (Heriningsih \& Marita, 2013). But in 
this case, activity ratio do not significantly influence the level of corruption. This study confirms Anthos (2018).

The Effect of Government Size in Moderating the effect of the Independence Ratio on Corruption Level:

The greater the government size, the more conflict of interest will occur. Government size strengthen the effect of independence ratio on the level of corruption. Independent ratio in provinces with bigger size will have higher corruption level.

The Effect of Government Size in Moderating the effect of the Activity Ratios on Corruption Level:

Government size do not moderate the effect of activity ratio on corruption. It may be happen because there are many factors affecting financial management itself. Furthermore, the size of a government will not guarantee the easiness of administration processes.

\section{Conclusions}

Audit result has positive significant effect on corruption level while government size significantly moderates the effect of financial performance on corruption level. This study uses follow-up recommendation indicator during the inspection period only. Future studies can use follow-up recommendations indicators with updated followup in recent years so that the data can be more representative. The adjusted $\mathrm{R}^{2}$ is only $38.1 \%$. Further research can add other variables that can explain the variability of the corruption level such as the Regional Financial Management Information System.

Based on the results of the study, the level of corruption in the provincial government fluctuates every year. Furthermore, it is suggested that the provincial government should strengthen its supervision and improve its internal control effectiveness to reduce corruption.

\section{References:}

Abror, S. and Haryanto. 2014. Government Audit and Corruption Control: Evidence from Panel Data Province in Indonesia. Journal of Diponegoro Accounting, 3, 1-11.

Balboa, J. and Medalla, E.M. 2006. Anti-Corruption and Governance: The Philippine Experience. APEC Study Center Consortium Conference, May, 29. Vietnam: APEC Study Center.

Barwi, I.E. and Solikhah, B. 2018. Analysis of Audit Result and Corruption Levels of Local Governments moderated by the effectiveness of SIPKD. Accounting Analysis Journal, 1-24. Semarang: Economic Faculty Universitas Negeri Semarang.

Cavill, S. and Sohail, M. 2007. Accountability Arrangements to Combat Corruption Literature Review, 76. Loughborough, UK: Water, Engineering and Development Centre. 
Connelly, B.L., Ireland, R.D. and Reutzel, C.R. 2011. Signaling Theory: A Review and Assessment, 37(1), 39-67. USA: Auburn University. https://doi.org/10.1177/0149206310388419.

De Asis, M.G. 2006. Reducing Corruption at the Local Level. New York: The World Bank.

Dunham, B.L. and Cronk, L. 2010. Applications of Signaling Theory to Contemporary Human Courtship. Dissertation. New Brunswick: State University of New Jersey.

Eisenhardt, K.M. 1989. Agency Theory: An Assessment and Review. Academy of Management Review, 14(1), 57-54.

Evans, J.H. and Patton, J.M. 1987. Signaling and Monitoring in Public-Sector Accounting, 25, 130-158.

Hartanto, R. and Prabohudono, A.N. 2013. Fiscal Decentralitation, Characteristics of Regional Governments and Corruption Level of Local Government in Indonesia year 2008 and 2010. Accounting National Simposium, XVI, 25-28. Manado: Universitas Sebelas Maret.

Heriningsih, S. and Marita, M. 2013. The Influence of Audit Opinion and Financial Performance of Local Government (Empirical Study of Local Government in Java Island). Economic Bulletin, 11(1). Yogyakarta: Universitas Pembangunan Nasional Yogyakarta.

Kivistö, J. 2007. Agency Theory as a Framework for the Government-University Relationship. Dissertation. Tampere: Faculty of Economics and Administration of the University of Tampere.

Liu, J. and Lin, B. 2012. Government auditing and corruption control: Evidence from China's provincial panel data. China Journal of Accounting Research, 5(2), 163-186. https://doi.org/10.1016/j.cjar.2012.01.002.

Masyitoh, R.D., Wardhani, R., Setyaningrum, D. 2010. The influence of Audit Opinion, Audit Findings, and Follow-up of Audit Result towards Corruption Perception on Local Government Year 2008-2010, 1-26. Dissertation submitted to Pascasarjana Ilmu Akuntansi FEB Universitas Indonesia.

Mugarura, N. 2016. Uncoupling the relationship between corruption and money laundering crimes. Journal of Financial Regulation and Compliance, 24(1), 74-89. https://doi.org/10.1108/JFRC-01-2014-0002.

Nurhasanah. 2016. Effectivity of Internal Control, Internal Audit, Characteristics of Institution and Corruption Cases. Journal of State Financial Governance \& Accountability. Jakarta: Ministry of Women's Empowerment and Child Protection.

Rini, R. and Damiati, L. 2017. Analysis of Government Audit Findings and Corruption Level in Province Government in Indonesia. Journal of Accounting and Business Dynamics, 4 (1), 73-90. Jakarta: USK Faculty of Economics and Business.

Shabbir, G. and Anwar, M. 2007. Determinants of corruption in developing countries. Pakistan Development Review, 46(4), 751-764. https://doi.org/10.2307/41261194.

Spence, M. 2002. Signaling in Retrospect and the Informational Structure of Markets. The American Economic Review, 92(3), 434-459.

Wahyudin, A. 2015. Research Metodology. Semarang: Unnes Press.

Wijaya, L.D. 2018. Corruption Cases in 2017. ICW: Kerugian Negara Rp 6,5 Triliun.

Zuhri, M. \& Soleh, A. 2014. Analysis of Local Government Financial Performance of Kabupaten Kaur. Ekombis Review, 187-195. 